\title{
EFFICIENCY OF LEACHING TESTS IN THE CONTEXT OF THE INFLUENCE OF THE FLY ASH ON THE ENVIRONMENT
}

\author{
Jan Kalembkiewicz' ${ }^{1}$ Elżbieta Sitarz-Palczak²
}

1 Department of Inorganic and Analytical Chemistry, Faculty of Chemistry, Rzeszow University of Technology, 6 Powstancow Warszawy Ave., 35-959 Rzeszow, Poland, e-mail: kalembic@prz.edu.pl

2 Department of Inorganic and Analytical Chemistry, Faculty of Chemistry, Rzeszow University of Technology, 6 Powstancow Warszawy Ave., 35-959 Rzeszow, Poland, e-mail: epalczak@prz.edu.pl

Received: 2014.09 .12

Accepted: 2014.10 .28

Published: 2015.01.02

\begin{abstract}
The leachability of heavy metals $(\mathrm{Cu}, \mathrm{Pb}$ and $\mathrm{Zn})$ from the coal fly ash samples was studied. The investigations executed using three leachability tests (USEPA, TCLP, ASTM). The effect of different parameters was determined (the diameter of ash grains, the kind of leaching solutions, $\mathrm{pH}$ of leaching solutions, the volume ratio of leaching solutions to the mass of ash samples, and the leaching time) on the leachability of the heavy metals from fly ash samples. Moreover, the influence of $\mathrm{pH}$ and changes in the redox potential of the leaching solutions as well as the presence of organic compounds that could potentially form complexes with metals and solubility changes of metals. The concentration of the metals studied $(\mathrm{Cu}, \mathrm{Pb}$ and $\mathrm{Zn})$ in all obtained solutions was determined by FAAS method. On the basis of the research investigations, optimal leachability conditions for $\mathrm{Cu}, \mathrm{Pb}$ and $\mathrm{Zn}$ from fly ash in this study have been determined. We have also found that $\mathrm{pH}$ of the leaching solution, and the presence of organic compounds which have a potential capacity of complexion the metals are the important factors in determining the solubility of $\mathrm{Cu}, \mathrm{Pb}$ and $\mathrm{Zn}$.
\end{abstract}

Keywords: heavy metals, fly ash, leaching test.

\section{INTRODUCTION}

Depositing waste at landfills and taking place in these uncontrolled processes physical, chemi$\mathrm{cal}$, and biological properties pose a serious threat to the environment. For this reason, the waste from storage must be evaluated together with organic designation degree of toxicity [WitkowskaKit 2000]. The degree of impact on the environment of waste containing contaminants in a form of toxic substances or harmful, depending on is not only the type and concentrations of these substances, but mainly their mobility. The mobility of pollutants contained in the waste, expressed as susceptibility to leaching them in water (also called leaching test), is the most important ecological sights indicator release for depositing waste at landfills. In Poland there is a lack of uniform standards and regulations relating to the preparation of aqueous extract and evaluate the reliability of the results obtained in the leaching test. Currently, two procedures are used to draw up the waste water. The first procedure is the result of the regulation of the Council of Ministers, 1997. The second procedure was established by Polish Standards [PN-Z-15009/1997]. The results obtained after the application of the above procedures do not indicate a total of the contents of the component in the waste, which can be subject to physicochemical change in the environment, give only an approximate indication in terms of assessing potential risks posed to the environment at the time referred to the waste.

Leaching tests can be divided into two main categories: 1. static tests and group and 2. dynamic tests and core barrels. In the static tests and group a quantity of the sample solution is specified and joined by a fixed period of time. The product of this connection is the leach substance. The main goal of the tests is a group that, 
at the end of the entire period of the process will be given a stable state of molecules. In the dynamic tests and column, the substance resulting in leaching constantly flows through the sample. Summary and comparison of group recruitment tests and column charts are contained in the following works [Zandi et al. 2007, Fällman, Aurell 1996, Egemen, Yurteri 1996, Lewin 1996, Wahlström 1996, Quevauviller et al. 1996].

Most waste in the field of employment is due to the structure of coal-fired power generation. As a result of burning coal solid waste (furnace waste) is produced: fly ash, slag, mixture of ash and slag, microspheres, boiler ash, flue gas desulfurization gypsum fluidized beds using limestone (wet method), wastes from flue gas desulfurization methods (dry and semi-dry methods), etc. [Galas et al. 2005]. Fly ash according to [Bilitewski et al. 2003] its the residues from the combustion of ground coal in amber furnaces, which are lifted of emissions and are captured by dust device. Ashes are contained in the mixture of dust-gas created from coal (hard coal and lignite).

Ash properties primarily depend on the chemical composition of non-flammable substances contained in different grades of coal burned [Pachowski 2002]. Fly ash, formed as a result of burning coal, may contain trace amounts of substances which during liquidation or disposal may be washed out, what poses a potential threat to the environment. Environmental conditions have a huge impact on the mobility of ash as well as on the physical and chemical properties. In order to simulate the behavior of the leached fly ashes in different environmental conditions and to reduce the discrepancies between the measurements made on the ground, and these have been developed in the laboratory, standard leaching tests. The most common tests used by eluting extraction procedures, i.e. the "Extraction" Procedure (EP) [Esakku et al 2008, Sophia, Swaminathan 2005], the "Toxicity by Characteristic Leaching Procedure" (TCLP) [Gitari et al. 2009, Lu et al. 2009, Jing et al 2006, Janus et al. 1998] and standardized extraction procedure developed by the American Society Of Testing And Materials (ASTM) [Dermata et al. 2004, Mangialardi 2003]. The leaching tests are widely used mainly as indicators to estimate the potential release of trace metals from the ash, in order to assess their impact on the environment in the process of rendering or deposition of fly ash under laboratory conditions [Sarode et al., 2010]. In addition, they allow the classification of trace elements of ash on the basis of their behavior during the leaching under different conditions and to identify the mechanisms of leaching [Fytiano, Tsaniklidi 1998, Hardaway et al. 1999, Janus et al. 1998, Praharaj et al. 2002, Sitarz-Palczak, Kalembkiewicz 2012].

Existing standard leaching schemes are insufficient because they do not depict any scenarios of waste liquidation or disposal, including ash. To reduce the surface storage of the ashes, new marketing options for their re-use are still searched for, which requires comprehensive and preceded by studies of their composition, physicochemical properties and susceptibility to further processing by various technologies and behavior in contact with various external factors.

The tests carried out in the framework of this work were to assess the impact on the environment from coal ash as they deposit in landfills and the certification of fitness for non-industrial utilization. To this end, studies were carried out regarding changes to the solubility of selected heavy metals $(\mathrm{Cu}, \mathrm{Pb}$ and $\mathrm{Zn})$ in the fly coal ash in anaerobic conditions.

\section{MATERIALS AND METHODS}

\section{Apparatus}

The flame atomic absorption spectrometer Perkin-Elmer 3100 Model (Shelton Instruments, CT USA) was used for $\mathrm{Cu}, \mathrm{Mn}$ and $\mathrm{Zn}$ determination in the solutions. Measurements were performed at wavelength $324.8 \mathrm{~nm}(\mathrm{Cu}), 217 \mathrm{~nm}$ $(\mathrm{Pb})$ and $213.9 \mathrm{~nm}(\mathrm{Zn})$ using a yellow fuel-rich air-acetylene flame (acetylene flow velocity 2.0 $\mathrm{dm}^{3} \cdot \mathrm{min}^{-1}$; air flow velocity $8.0 \mathrm{dm}^{3} \cdot \mathrm{min}^{-1}$ ) and burner height of $3 \mathrm{~mm}$. The analytical lines were selected using a slit width $0.7 \mathrm{~mm}$ and followed by [Perkin-Elmer 1982]. Hollow cathode lamp at $10 \mathrm{~mA}(\mathrm{Cu}$ and $\mathrm{Zn}), 20 \mathrm{~mA}(\mathrm{~Pb})$ was used. The centrifuge tube-test Model WE 1 (Precision Engineering, Poland) - was used for the centrifugation of the soil extracts at the at appropriate rotary speed of $3000 \mathrm{rpm}$. The universal laboratory shaker Vibramax 100 Model (Heidolph Instruments, Germany) and a hot plate HP 88720-26 Model (Barnstead/Thermolyne, USA) were used for the extraction. The $\mathrm{pH}$ of the extraction solutions was determined with a $\mathrm{pH}$ meter CPI-551 Model (Elmetron, Poland) supplied with a glass combination electrode (Eurosensor, Poland). 


\section{Reagents and solutions}

All chemicals and reagents were of analytical grade or higher purity and were obtained from $\mathrm{POCH}$, Gliwice, Poland. The solutions were prepared by dissolving appropriate compounds in double-distilled water from the Water Purification System (SolPure 7 POLL LAB, Poland). The reagents were prepared and stored in clean polyethylene bottles. Glassware and plastic ware (PE) used throughout the experimental work were previously soaked in $10 \%$ nitric acid bath overnight and washed thoroughly in double distilled water. Standard solutions were prepared from standard solutions for atomic absorption (Sigma-Aldrich Chemie GmbH, Switzerland) - the concentration of all metals in standard solutions were the same and equals $1.000 \mu \mathrm{g} \cdot \mathrm{cm}^{-3}$ in $1 \%$ of $\mathrm{HNO}_{3}$. Working standard solutions containing $\mathrm{Cu}, \mathrm{Pb}$ and $\mathrm{Zn}$ were prepared by serial dilution of the appropriately of standard solution for atomic absorption.

\section{Sample collection and preparation}

Coal fly ash samples used for the experiments were collected from the electric filter from Rzeszów S.A power-plant (Rzeszów, Poland). The $0.5 \mathrm{~kg}$ sample was prepared from overall air-dried $10 \mathrm{~kg}$ sample by a "quarterning" method - according to Polish Branch Standard [BN-81/0623$01]$ procedure. After that, the air-dried ash was sieved, initially through a laboratory sieve of 1 $\mathrm{mm}$ diameter, and then milled in an agate mortar to fine powder $(\varphi \leq 100 \mu \mathrm{m})$ - according to Polish Standard [PN-77/G-04528/00].

\section{Fly ash}

Physicochemical characteristics of ash samples included determination of $\mathrm{pH}$ using potentiometric method [PN-ISO-10390]; determination of organic carbon content - Tiurin method [PN95-Z-15005] and composition of granulometric by using the sieve methods [PN-R-04032]. The total content of metals is obtained after mineralization in a mixture of concentrated $\mathrm{HNO}_{3}$ acid, $\mathrm{HF}$ and $\mathrm{HCl}$ under conditions described in the work [Sitarz-Palczak, Kalembkiewicz 2008].

\section{Standard leaching tests}

Three standard leaching tests (USEPA, TCLP, ASTM) were selected for this study to determine stability of trace elements $(\mathrm{Cu}, \mathrm{Pb}$ and $\mathrm{Zn})$ in fly ash samples under three different conditions (Table 1). Leaching tests were carried out based on the principles laid in standard procedures. To obtain USEPA, TCLP and ASTM extracts $5 \mathrm{~g}$ of fly ash was agitated in polyethylene bottle containing $100 \mathrm{~cm}^{3}$ of extracting medium for the specified time periods of 24 and $18 \mathrm{~h}$, respectively. After the required period of agitation, all extracts were stirred with a glass rod and filtered through 0.45 $\mu \mathrm{m}$ filter paper. The filtrates were acidified with a concentrated $\mathrm{HNO}_{3}$ addition and transferred to a polyethylene bottle and stored in a cool dry place for further analysis by atomic absorption spectrophotometry (FAAS). All extractions were carried out as triplicate runs.

\section{Effect of parameters of ash and leaching process}

The effect of selected parameters on the output samples of ash (particle diameter ash) and leaching process (a type of leaching solution, the $\mathrm{pH}$ of the solution, the ratio of volume of leaching solution to mas of the sample and the influence of the ash leaching time) on the leaching of heavy metals from the ash samples was studied. In order to determine the effect of particle diameter ash and the type of leaching solution has three standard tests of leaching: USEPA TCLP, and ASTM (Table 1), with respect to the fraction of the ashes received after the sieve analysis. The proceedings were the same as in the case of a standard leaching procedures described above. In order to determine the effect of $\mathrm{pH}$ leaching solution $(2.5 \%$ $\mathrm{CH}_{3} \mathrm{COOH}$ ) on the leachability of metals from the ash particle diameter $\varphi=1.5 \mathrm{~mm}$ done series of $2.5 \% \mathrm{CH}_{3} \mathrm{COOH}$ that $\mathrm{pH}$ values: $2 ; 3 ; 4 ; 7$ and 12 . Adjust the $\mathrm{pH}$ was carried out using $0.1 \mathrm{~mol} \cdot \mathrm{dm}^{-3}$ $\mathrm{HCl}$ and $0.1 \mathrm{~mol} \cdot \mathrm{dm}^{-3} \mathrm{NaOH}$. Then use the so prepared solutions $2.5 \% \mathrm{CH}_{3} \mathrm{COOH}$ fixed $\mathrm{pH}$ values were leaching of metals $(\mathrm{Cu}, \mathrm{Pb}$ and $\mathrm{Zn})$ under the conditions given in Table 1 - in relation to a standard TCLP procedure. To determine the influence of relative elution volume $\left[\mathrm{cm}^{3}\right]$ to mass $[\mathrm{g}]$ on the leaching $\mathrm{Cu}, \mathrm{Pb}$ and $\mathrm{Zn}$ with samples of ash made a series of leaching tests according to the standard TCLP procedure, in which the ratio of L:S $\left[\mathrm{cm}^{3}: \mathrm{g}\right]$ was, respectively: $1: 1 ; 2: 1 ; 5: 1$; 10: 1, 20: 1 and 50: 1. In order to determine the influence of time on the leachability $\mathrm{Cu}, \mathrm{Pb}$ and $\mathrm{Zn}$ from ash fractions with a diameter of $\varphi=1.5$ $\mathrm{mm}$ using standard leaching test, the following conditions were established as optimal i.e. leach- 
Table 1. Conditions of leaching tests

\begin{tabular}{|l|c|c|c|}
\hline \multicolumn{1}{|c|}{ Tests conditions } & $\begin{array}{c}\text { USEPA } \\
\text { [USEPA 1987] }\end{array}$ & $\begin{array}{c}\text { TCLP } \\
\text { [TCLP 1311 1990] }\end{array}$ & $\begin{array}{c}\text { ASTM } \\
\text { [ASTM D 3987-85 2001] }\end{array}$ \\
\hline Leaching solution & $0,5{\mathrm{~mol} / \mathrm{dm}^{-3} \text { nitric acid }}^{\prime}$ & $2,5 \%$ acetic acid & Distilled water \\
\hline Liquid to solid ratio $\left[\mathrm{cm}^{3} / \mathrm{g}\right]$ & $20: 1$ & $20: 1$ & $20: 1$ \\
\hline Leaching time $[\mathrm{h}]$ & 24 & 24 & $6.3 \pm 0.1$ \\
\hline $\mathrm{pH}$ of leachig solutions & $0.6 \pm 0.1$ & $4.0 \pm 0,1$ & $19-25$ \\
\hline Temperature $\left[{ }^{\circ} \mathrm{C}\right]$ & $19-25$ & $19-25$ & 1 \\
\hline Number extraction & 1 & 1 & 24 \\
\hline
\end{tabular}

ing solutions $2.5 \% \mathrm{CH}_{3} \mathrm{COOH}$ (TCLP); $\mathrm{pH}=2.5$; the ratio of the volume of leaching solution to the mass of the sample $\mathrm{L}: \mathrm{S}=50: 1\left[\mathrm{~cm}^{3}: \mathrm{g}\right]$. Assuming the following leaching times: 0,$5 ; 2 ; 4 ; 6 ; 8,12$ and $24 \mathrm{~h}$. subsequent procedure was the same as in the case of leaching procedures described above.

Effects of selected organic compounds with a potential capacity of complexion the metals on the solubility of $\mathrm{Cu}, \mathrm{Pb}$ and $\mathrm{Zn}$ in anaerobic conditions

In order to determine the effect of complexion substances on the contents of selected metals in the soluble forms contained in the ashes two series of complete extractions by shaking samples of ash were performed, with the complexion addition substances: citric acid or tartaric acid with the following concentrations: 10, 20, 40, 100 $\mathrm{mg} \cdot \mathrm{dm}^{-3}$ corresponding $6.25 ; 12.50 ; 25.00 ; 62,50$ $\mathrm{mg} \cdot \mathrm{kg}^{-1}$ ash. The solubility change of $\mathrm{Cu}, \mathrm{Pb}$ and $\mathrm{Zn}$ in anaerobic conditions was studied in a series of incubation of samples of ash with the addition of organic substances constituting a potential source of easily accessible coal they were glucose and tartaric acid with a concentration of 200 $\mathrm{mg} \cdot \mathrm{dm}^{-3}$. Incubations are performed at in confinement without access of oxygen for a period of 7 days, stirring the sample for 10 minutes from time to time to ensure the balance between the permanent and the solution. After the incubation was carried out through the extraction conditions of shaking in leaching tests (USEPA and TCLP), which is given in Table 1.

\section{RESULTS AND DISCUSSION}

Basic physicochemical properties of ash were presented in Table 2. On the basis of the obtained results, it was concluded that coal ash shows slightly alkaline $\mathrm{pH}$. Working with [Łączny 2002] it is known that the energy (fly ashes) compounds of heavy metals present in the waste are in slightly alkaline environment, because the ions of these metals in this environment are generally less mobile complex compounds. If intended for the storage of fly ash, or other energy waste will have basic character, the main threat to the environment will be releasing such compounds as sodium, potassium and calcium sulphate. So in the case of investigational ash (wood and coal) there is no risk of wash of heavy metal ions with alkaline base nature of these wastes. Organic carbon content in the ash residue of unburned carbon [ $\mathrm{Su}$, Wong 2003]. Based on the results of the analysis, the granulometric composition it was found that the greatest part is the fraction of particulate matter, which is consistent with the results obtained by [Antonkiewicz 2014]. The total content of trace metals in the ash is varied. Since they all occur at concentrations above $50 \mathrm{mg} \cdot \mathrm{kg}^{-1}$ can they have a large impact on the environment (Table 2). In a view of the fact that ash is a heterogeneous material, elements contained therein are not evenly distributed. The content of organic carbon assessed in fly ash reveal the presence of unburned coal residues. The surface layer is enriched in

Table 2. Physicochemical properties of fly ash (the results presented reflect values of data taken from 10 samples)

\begin{tabular}{|l|c|}
\hline \multicolumn{1}{|c|}{ Parameter } & Value of parameter \\
\hline $\mathrm{pH}:$ & 9.1 \\
$\mathrm{H}_{2} \mathrm{O}$ & 8.9 \\
$1 \mathrm{~mol} \cdot \mathrm{dm}^{-3} \mathrm{KCl}$ & 53.9 \\
\hline Content of organic carbon $\left[\mathrm{g}^{\mathrm{kg}}{ }^{-1}\right]$ & \\
\hline Texture $[\%]:$ & 0.9 \\
Clay $(0-2 \mu \mathrm{m})$ & 75.7 \\
Silt $(2-50 \mu \mathrm{m})$ & 23.4 \\
Sand $(>50 \mu \mathrm{m})$ & \\
\hline Total content $\left[\mathrm{mg} \cdot \mathrm{kg}^{-1}\right]$ of metal & $63.7( \pm 3.9)$ \\
$\mathrm{Cu}$ & $101.2( \pm 4.6)$ \\
$\mathrm{Pb}$ & $200.0( \pm 4.1)$ \\
$\mathrm{Zn}$ &
\end{tabular}


copper and zinc, while lead is distributed evenly between the sensor and the surface of the grains [Izquierdo, Quero 2012].

\section{Standard leaching tests}

In natural conditions (under the influence of atmospheric conditions and the presence of microorganisms - in landfills there are numerous physical, chemical and biological processes, not subject to the control. These processes give rise to, first and foremost, the aging of the deposited material, its weathered and leaching. Aging is generally to reduce the solubility, and weathered to the creation of partially soluble products. The leachability applies to an easily soluble metal form, present in the waste, i.e. first of all, salt, in which the composition has sulfates of calcium, potassium, sodium and magnesium. The immediate effect of leaching is an increase in permeability of the deposits, increased salinity of groundwater and surface water. The leachability of $\mathrm{Cu}, \mathrm{Pb}$ and $\mathrm{Zn}$ in fly ash obtained after the application of three standard leaching tests (USEPA TCLP and ASTM) was presented in Table 3. The highest degree of leaching for $\mathrm{Pb}$ of $56.8 \%$ in relation to the total content of $\mathrm{Pb}$ in the fly ash, were obtained using the USEPA test; respectively $22.3 \%$ was obtained by means of TCLP procedure. While the ASTM test using distilled water was obtained the lowest value of leaching equal to $2.5 \%$ in relation to the total contents of $\mathrm{Pb}$ in the fly ash. The degree of leaching for copper was $62.7 \%$ using the USEPA test and only $19.6 \%$ in the case of the TCLP test in relation to the total content of $\mathrm{Cu}$ in the fly ash. The leachability of copper in the case of ASTM test was below the limit of detection for this metal, as determined by FAAS method. Zinc showed the greatest percent- age of leachability using the USEPA procedures and it was $35 \%$ in relation to the total content of the metal in the ashes. and $14.6 \%$ after applying the TCLP test. The leachability of Zn in ASTM test does not exceed the limit of detection for the determination of this metal by the FAAS method. In summary, containing a test in which the largest were the concentration of soluble forms in respect of all designated metals in coal ash is the USEPA. In the light of the above, it can be concluded that this test shows the highest efficiency in relation to the determined metals $\mathrm{Cu}, \mathrm{Pb}$ and $\mathrm{Zn}$. The USEPA procedure is more effective due to aggressive conditions during the leaching of metals. Taking into account the value of the degree of leaching of individual elements, it can be concluded that the degree of leaching of $\mathrm{Cu}, \mathrm{Pb}$ and $\mathrm{Zn}$ is decreasing in the following series: $\mathrm{Cu}>\mathrm{Pb}>\mathrm{Zn}$. In spite of all processes taking place in the environment it is suggested that the most appropriate and best simulating natural conditions is ASTM procedure, in which the eluting solution is distilled water. However, research carried out for the TCLP test may be helpful in the diagnosis of possible risks which might occur in the event of "acid rain".

Statistical analysis of the results obtained on the concentrations of metals in the soluble forms, and their total content in the ash was carried out using a linear regression. Figure 1 shows the obtained relationship between leachability of $\mathrm{Cu}$, $\mathrm{Pb}$ and $\mathrm{Zn}$ in relation of the total content of these metals in studied the ashes after application of the TCLP test. On the basis of the obtained result, it was found that an important relationship between the soluble forms of metals and their total content in fly ash prove the obtained correlation values of the coefficients, which are : $\mathrm{Zn}-0.68, \mathrm{Cu}-0.83$, $\mathrm{Pb}-0.82$. The results of the studies on the content of the soluble forms $\mathrm{Cu}, \mathrm{Pb}$ and $\mathrm{Zn}$ in fly ash al-

Table 3. Summary of the concentrations of $\mathrm{Cu}, \mathrm{Pb}$ and $\mathrm{Zn}$ in the soluble forms and relative leaching of these metals by USEPA TCLP and ASTM procedures (concentration of metal in the fly ash and the confidence interval were given for $\mathrm{n}=10$ at $\mathrm{p}=95 \%$ )

\begin{tabular}{|c|c|c|c|c|}
\hline Procedure & Concentration of metals $\left[\mathrm{mg} \cdot \mathrm{kg}^{-1}\right]$ & $\mathrm{Cu}$ & $\mathrm{Pb}$ & $\mathrm{Zn}$ \\
\hline \multirow{2}{*}{ USEPA } & Leachability & $40.0( \pm 2.6)$ & $57.5( \pm 2.9)$ & $70( \pm 3.5)$ \\
\hline & Relative leaching [\%] & 62.7 & 56.8 & 35.0 \\
\hline \multirow{2}{*}{ TCLP } & Leachability & $12.5( \pm 0.7)$ & $22.6( \pm 1.1)$ & $29.1( \pm 1.6)$ \\
\hline & Relative leaching [\%] & 19.6 & 22.3 & 14.6 \\
\hline \multirow{2}{*}{ ASTM } & Leachability & $<$ I. d. & $2.5( \pm 0.2)$ & $<$ l. d. \\
\hline & Relative leaching [\%] & - & 2.5 & $<$ I. d. \\
\hline \multicolumn{2}{|c|}{ Leachability limit [Rozporzadzenie...2006] } & 0.05 & 0.5 & 2.0 \\
\hline
\end{tabular}

I. d. - limit of detection by FAAS method. 


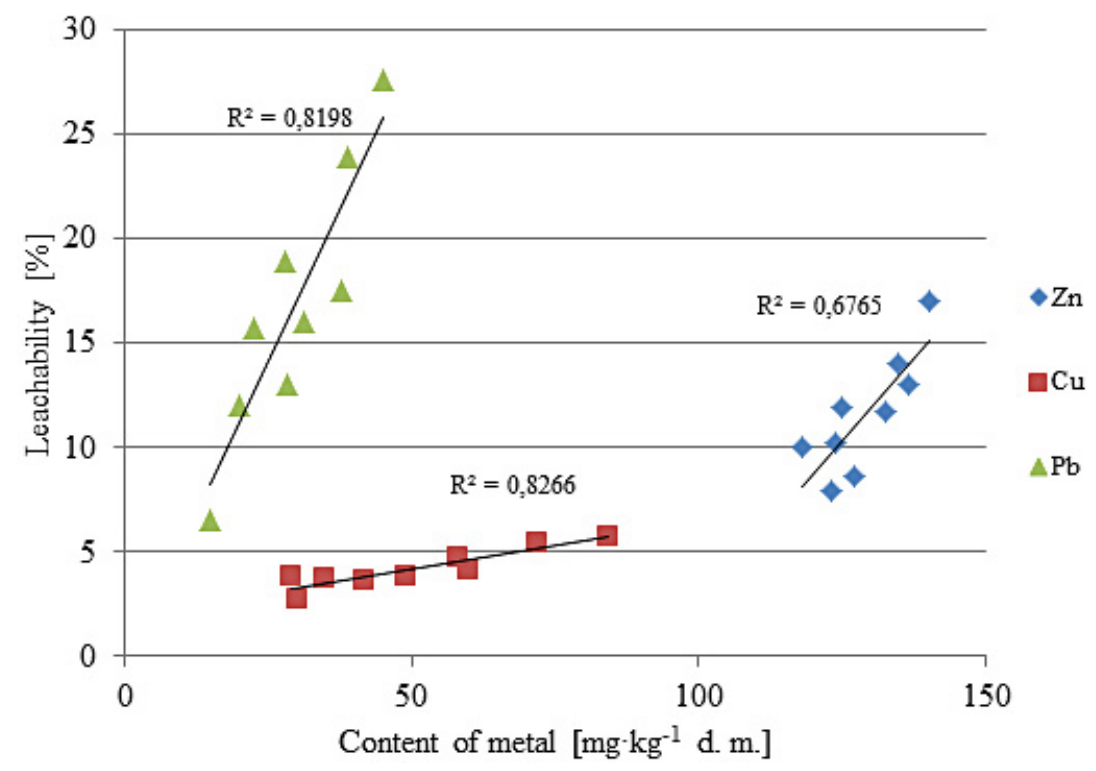

Figure 1. Relation between leachability of $\mathrm{Zn}, \mathrm{Cu}$ and $\mathrm{Pb}$ and total concentration this metals in fly ash after the TCLP test used

low an approximate assessment of the risks posed to the water - soil environment at the time by a specified waste. For this purpose, the concentrations of trace investigated metals received in the soluble forms in the ash were compared with the limit values for wastewater entering into waters or into the ground, assembled in a Table 3. On the basis of the obtained results, it was found that the concentration of $\mathrm{Zn}$ obtained after leaching at the USEPA, TCLP and ASTM tests exceed acceptable concentrations for this metal for wastewater entering into waters or into the ground. The same situation occurs in the case of $\mathrm{Cu}$ and $\mathrm{Pb}$ after leaching with USEPA TCLP, tests from the fly ash. The obtained results, due to the heterogeneity of the test material, should be verified on the basis of the follow-up testing of leachability of metals from the ashes.

In assessing the dangers of fly ash containing pollution in a form of heavy metals, in addition to the degree of leaching, one should take into account the additional effect of the aging of waste. It can be both beneficial and detrimental. This is a very important ecological factor for the future in relation to the waste deposited in landfills. It may actually happen that the waste with low leaching today become more washed out after a few years, or waste with high leaching become harmless after a few years of storage. Linked to this need for constant monitoring of ash storage facilities, which, in the light of the obtained results pose a risk of contamination of the environment water near the landfill.

\section{Effect of parameters of ash and leaching process}

There is a number of factors that may affect the leach of each constituent elements in fly ash leaching tests. Some of these factors are related to the properties and composition of fly ash, others depend on conditions of leaching [Zandi et al., 2007]. Test conditions (LS ratio, leachant $\mathrm{pH}$ and leaching time) have a great impact on these results. The conditions for measuring potential leachability have not been clearly addressed in literature; there are a few contradictory studies on the principles of leaching and effects of control factors such as $\mathrm{pH}$ and LS ratio on fly ash leaching behavior [Fällman 1997].

\section{Particle size of fly ash}

Fly ash have poorly developed a pore structure. The degree of development of the structure of the surface of the grains and the size of the specific surface area to a large extent determine the susceptibility of the ashes on the leaching of soluble parts from them. Therefore, it can be seen, that both the grain diameter as well as their appropriate size will determine indirectly the leaching solutions on the tested metals. Figures 2 - 4 illustrate the effect of particle diameter on the leachability of soluble forms of $\mathrm{Cu}, \mathrm{Pb}$ and $\mathrm{Zn}$ from the fly ash using the USEPA TCLP tests. On the basis of the results presented in Figures 2 - 4, it was concluded that particle diameter of fly ash has a significant effect on the leachability 


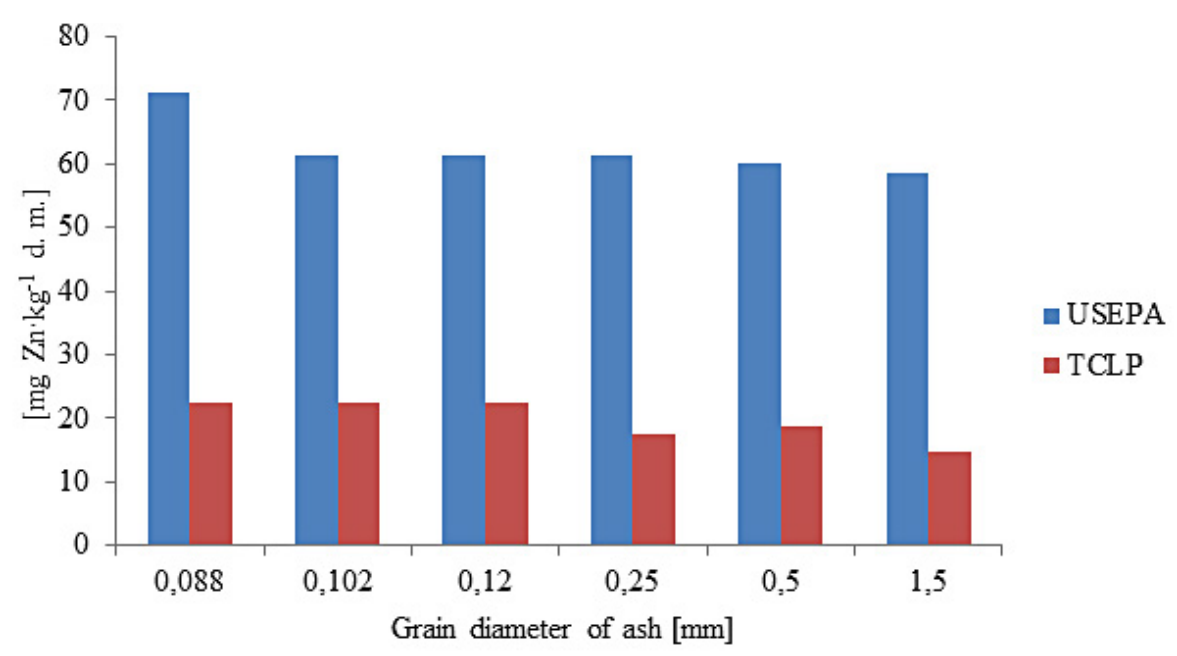

Figure 2. Content of $\mathrm{Zn}$ in the soluble forms in the fly ash with different grain diameter of ash obtained by the use of the leaching test (USEPA, TCLP) and determined by FAAS method

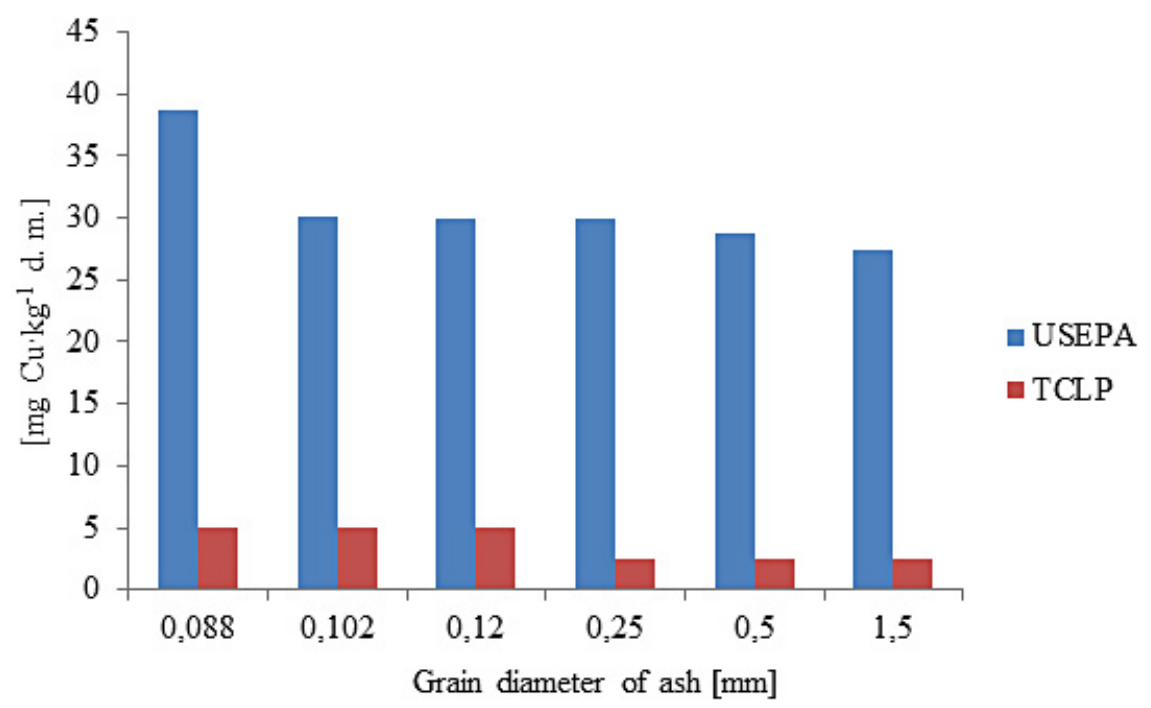

Figure 3. Content of $\mathrm{Cu}$ in the soluble forms in the fly ash with different grain diameter of ash obtained by the use of the leaching test (USEPA, TCLP) and determined by FAAS method

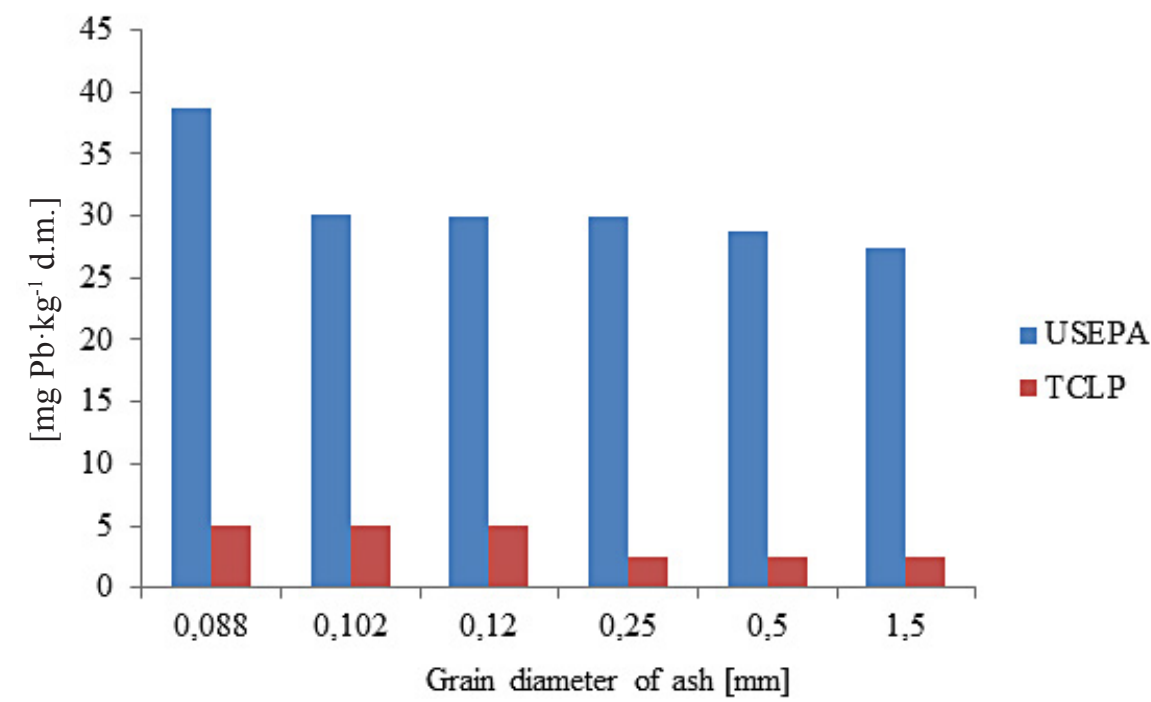

Figure 4. Content of $\mathrm{Pb}$ in the soluble forms in the fly ash with different grain diameter of ash obtained by the use of the leaching test (USEPA, TCLP) and determined by FAAS method 
of soluble forms of $\mathrm{Zn}$ and $\mathrm{Cu}$, as well as in the application of the tests USEPA and TCLP. With regard to both the highest of leaching metals were received by the ash of $0.088 \mathrm{~mm}$ diameter and solution of $\mathrm{HNO}_{3}$ (USEPA) respectively, for was equal to $72 \mathrm{mg} \cdot \mathrm{kg}^{-1}$, while for $\mathrm{Cu} 38 \mathrm{mg} \cdot \mathrm{kg}^{-1}$ in respect of the dry mass of the ash. The effect of particle of diameter of ash on leachability of $\mathrm{Pb}$ shows an inverse relationship, as in the case of other metals by applying USEPA and TCLP tests, namely the leachability of $\mathrm{Pb}$ increases with ash particle diameter. The leachability of lead using the USEPA test shows the highest concentration of soluble forms of metal particle diameter ash equal: 0.088 and $1.5 \mathrm{~mm}$. The lowest $\mathrm{Pb}$ content in the soluble forms was received for grain diameter of ash equals $0.102 \mathrm{~mm}$.

\section{Leachability as a function of $\mathrm{pH}$}

The $\mathrm{pH}$ of the solution is very important as it determines the surface charge of the fly ash, and the degree of ionization and speciation of the elements in solution. The interactions between the charged ions in solution and the surface of fly ash particles contribute to release or adsorption of species. The results shown in Figure 5 indicate the trend of $\mathrm{pH}$ release of $\mathrm{Cu}, \mathrm{Pb}$ and $\mathrm{Zn}$. The concentration of soluble forms of all studied metals in fly ash decreases with increasing alkalinity of the leaching solution. $\mathrm{pH}$ in the range of 2 to 3 found the largest leachability for all heavy metals tested; respectively for Zn $25-15 \%$, copper $31-19 \%$ and lead $36-26 \%$ in relation to the total contents of the metals in the fly ash. Low concentrations of these metals were observed in leachate solution $(2.5 \%$ $\left.\mathrm{CH}_{3} \mathrm{OOH}\right)$ at high $\mathrm{pH}(>9)$ but increased at $\mathrm{pH}$ $<9$. The leaching trend for these metals indicates the dependence of the release of some metals on the dissolution of hydrous oxides of iron and manganese. $\mathrm{Mn}$ and $\mathrm{Fe}$-oxides present in fly ash are formed during combustion of coal, and on hydrolysis form $\mathrm{Mn}$ and $\mathrm{Fe}$ hydroxides. Trace metals, such as $\mathrm{Cu}$ and $\mathrm{Pb}$ are associated with these hydroxides and on dissolution of these hydroxides, the trace metals are bound to be released into solution. Adsorption/desorption also plays a role in controlling the concentrations of heavy metals.

Fly ash material generates an alkaline $\mathrm{pH}$ within a few minutes of contact with water in most cases, due to higher quantities of soluble basic oxides than the soluble acid phases [Choi et al 2002, Reardon et al. 1995]. Several studies [Cho et al. 2005, Lee, Saunders 2003, Steenari et al. 1999] have shown that at higher $\mathrm{pH}$, the surfaces of the fly ash particles are negatively charged. This would lead to increase in the adsorption of most heavy metals from the solution. The increase in adsorption of heavy metals ions in fly ash solutions at higher $\mathrm{pH}(>10)$ may also be attributed to calcium content which provides alkalinity in the system raising the $\mathrm{pH}$ to strongly alkaline values, thereby facilitating the uptake of metal ions by the fly ash.

The $\mathrm{pH}$ of the environment has a great impact an chemical speciation of leachate elements from fly ash in the aqueous environment except for highly soluble elements which are mobile under both acidic and basic conditions. The difference

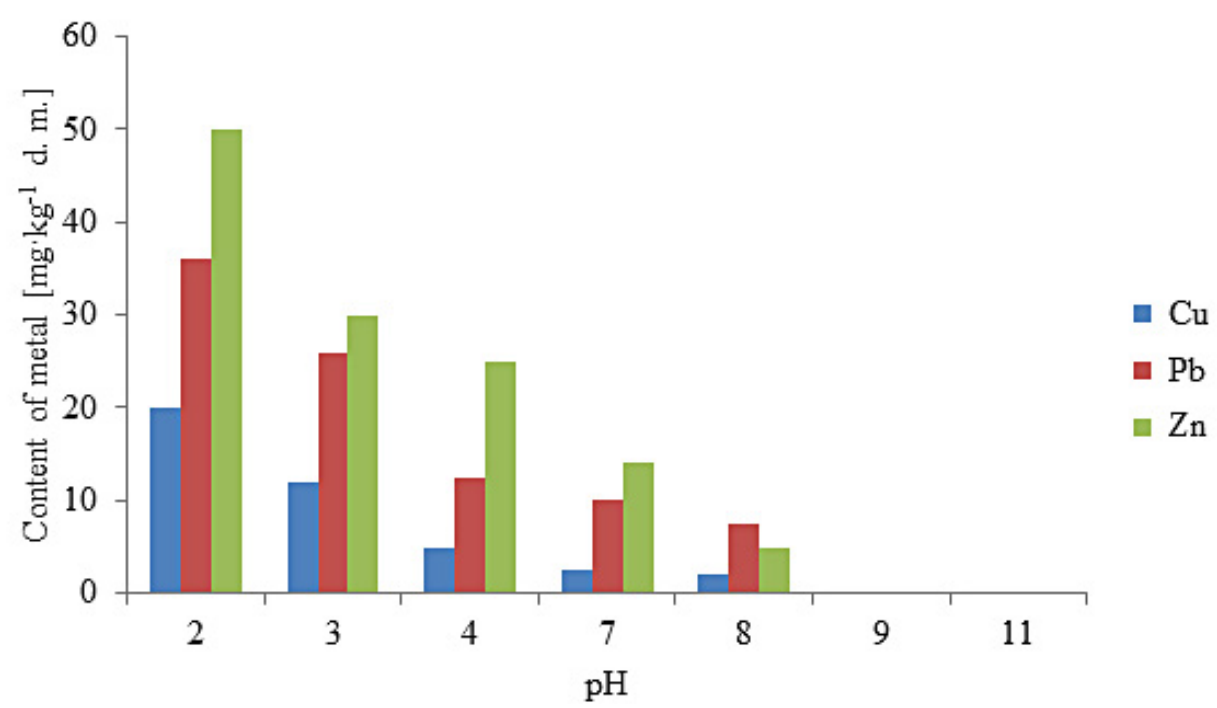

Figure 5. Change of content of $\mathrm{Cu}, \mathrm{Pb}, \mathrm{Zn}$ in the soluble forms in the fly ash under the influence of changes to the influence $\mathrm{pH}$ of leaching solution obtained after the TCLP procedure 
between total quantity of element in the fly ash and the potentially leachable constituent is due to structure and mineralogy of the fly ash and associations of the element major insoluble phases present in the fly ash.

Solubility of metal compounds is an important property that allows metals to penetration into the structure of the porous adsorbent. The concentration of such speciation forms of metals as: $\mathrm{MOH}^{+}, \mathrm{M}(\mathrm{OH})_{2}, \mathrm{M}(\mathrm{OH})_{3}{ }^{-} \mathrm{M}(\mathrm{OH})_{4}{ }^{2-}$ at $\mathrm{pH}$ $6<$ are too small to affect the sorption process the dominant forms of metal $\mathrm{M}^{2+}(\mathrm{M}=\mathrm{Cu}, \mathrm{Zn}$, $\mathrm{Pb}$ ) [Ho, et al., 2002]. This is confirmed by the data presented in Figure 6 the speciation graph of metal ions, whose curves are compatible with the data from literature [Zirino, Yamamoto, 1972, Cuppett et al. 2006, Cárdenas López et al. 2007, Deliyanni et al., 2007]. They have been generated on the basis of the program Medusa [http://www.kemi.kth.se/medusa/]. The speciation curves for the different ions of heavy metals indicate that different forms dominate in the solution within a certain range of $\mathrm{pH}$; for example $\mathrm{Zn}^{2+}$ is a dominant form in solution at $\mathrm{pH}<6$. Above this $\mathrm{pH}$ in solution increases the concentration of $\mathrm{ZnOH}^{+}$and $\mathrm{ZnO}$. With regard to the adsorption of $\mathrm{Cu}$ and $\mathrm{Pb}$ it should be kept in mind that these speciation forms of metals, or simple ions $\mathrm{Cu}^{2+}$ and $\mathrm{Pb}^{2+}$ have mainly to $\mathrm{pH}$ about 6 , above which exponentially increases the concentration of $\mathrm{CuO}$ and $\mathrm{Pb}(\mathrm{OH})_{2}$. In general, there are different mechanisms that may control the release of a particular constituent from a particular fly ash in an aqueous environment. Highly soluble elements available on the surface of the fly ash often fall into the category of available controlled leaching if the concentration released into the leachant is limited only by the amount of the element in the fly ash. These element are expected to become mobile soon after contact with aqueous environment and leach at high concentrations. Leachability of some other constituents may be solubility controlled where leachability of elements in the fly ash can be described by dissolution and precipitation processes.

\section{Leachability as a function of redox potential}

The leaching of some metals e.g., Fe, Cr, As can depend significantly on the redox conditions. The redox conditions can change due to the access of air to the sample during the storage or in performing the leaching test [Wahlström1996]. The results concerning the effect of the potential redox on the contents of metals in the soluble form in the fly ash are shown in Table 4. At high values of the potential $(\approx 170 \mathrm{mV})$, the concentration of $\mathrm{Cu}, \mathrm{Pb}$ and $\mathrm{Zn}$ in the soluble forms are highest and are respectively equal to: $\mathrm{Cu}-37.5 ; \mathrm{Pb}-50$ and $\mathrm{Zn}-80$ $\mathrm{mg} \cdot \mathrm{kg}^{-1}$. At the same time, as the high value of the potential suggests, these metals are present in the oxidized forms by taking the highest oxidation: $\mathrm{Cu}^{\mathrm{II}}, \mathrm{Pb}^{\mathrm{IV}}$ and $\mathrm{Zn}^{\mathrm{II}}$. Along with the decline in the potential decrease the content of $\mathrm{Cu}, \mathrm{Pb}$ and $\mathrm{Zn}$ in the soluble forms, which testifies to their presence in the reduced forms.

\section{Leachability as a function of L:S ratio}

The ratio of the volume of leaching solution to the mass of sample fly ash $(\mathrm{L}: \mathrm{S})$ is one of the more important factors affecting the leaching of trace elements from the ashes samples. The most commonly used ratio of the liquid phase to the solid phase $(\mathrm{L}: \mathrm{S})$ is located in the range $(10-20): 1$, but with a higher ratio, for example 50:1, the leaching substance is more easily mixed with fly ash, and trace components are increasingly leached away from the seeds of the ash. The results shown in Table 5 fully confirmed the correlation.

Table 4. Effect of the redox potential of leaching solutions on the content of $\mathrm{Cu}, \mathrm{Pb}$ and $\mathrm{Zn}$ in the soluble form in the fly ash obtained after the TCLP procedure (concentration of metal in the fly ash and the confidence interval were given for $\mathrm{n}=6$ at $\mathrm{p}=95 \%$ )

\begin{tabular}{|c|c|c|c|c|c|}
\hline \multirow{2}{*}{$\begin{array}{c}\text { Value of SEM [mV] of } \\
\text { leaching solutions }\end{array}$} & $\begin{array}{c}\text { Value of SEM [mV] } \\
\text { before leaching }\end{array}$ & $\begin{array}{c}\text { Value of SEM } \\
\text { after leaching }\end{array}$ & \multicolumn{3}{|c|}{ Concentration of soluble forms of metal $\left[\mathrm{mg}^{-} \mathrm{kg}^{-1}\right]$} \\
\cline { 4 - 6 } & 178 & 170 & $37.5( \pm 5.5)$ & $50.0( \pm 7.2)$ & $70,0( \pm 9.5)$ \\
\hline 189 & 159 & 140 & $20.5( \pm 2.8)$ & $26.0( \pm 3.3)$ & $55,0( \pm 5.8)$ \\
\hline 162 & 95 & 89 & $5.0( \pm)$ & $12.5( \pm 1.5)$ & $25.0( \pm 6.5)$ \\
\hline 100 & -20 & -10 & $2.5( \pm 1.1)$ & $12.5( \pm 3.1)$ & $7.5( \pm 1.8)$ \\
\hline-25 & -96 & -88 & $<$ l. d. & $5.0( \pm 1.9)$ & $5.0( \pm 1.7)$ \\
\hline-96 & -167 & -158 & $<$ l. d. & $<$ l. d. & $<$ I. d. \\
\hline-161 & &
\end{tabular}

I. d. - limit of detection by FAAS method. 
a) $\left[\mathrm{Cu}^{2+}\right]_{\mathrm{TOT}}=10.00 \mu \mathrm{M}$

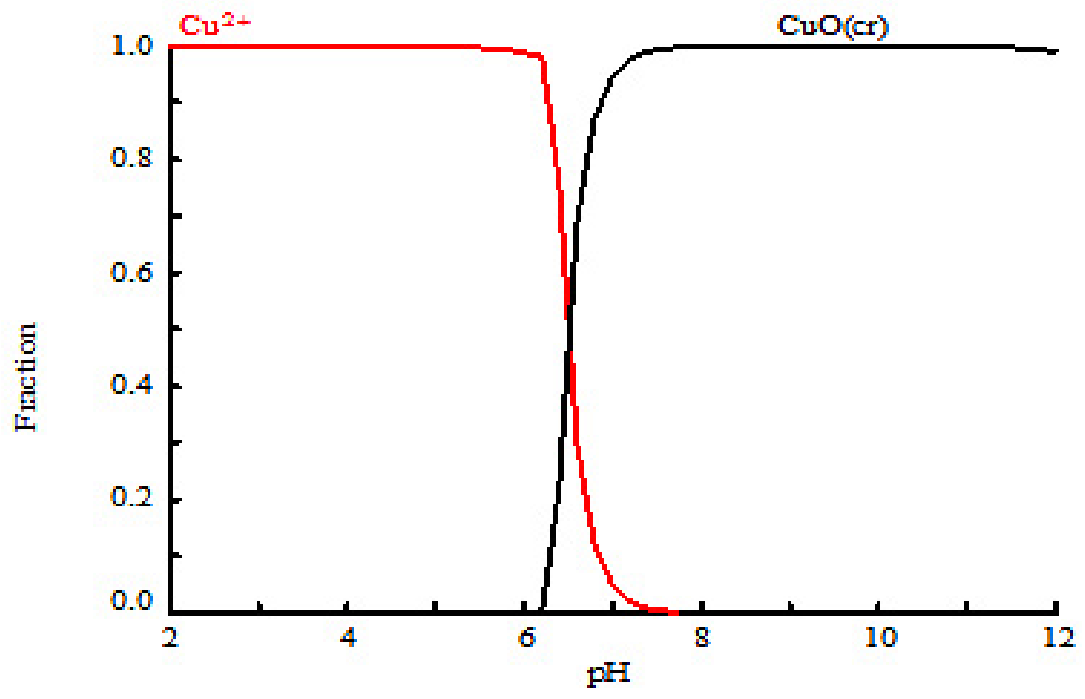

b) $\left[\mathrm{Zn}^{2+}\right]_{\text {TOT }}=10.00 \mu \mathrm{M}$

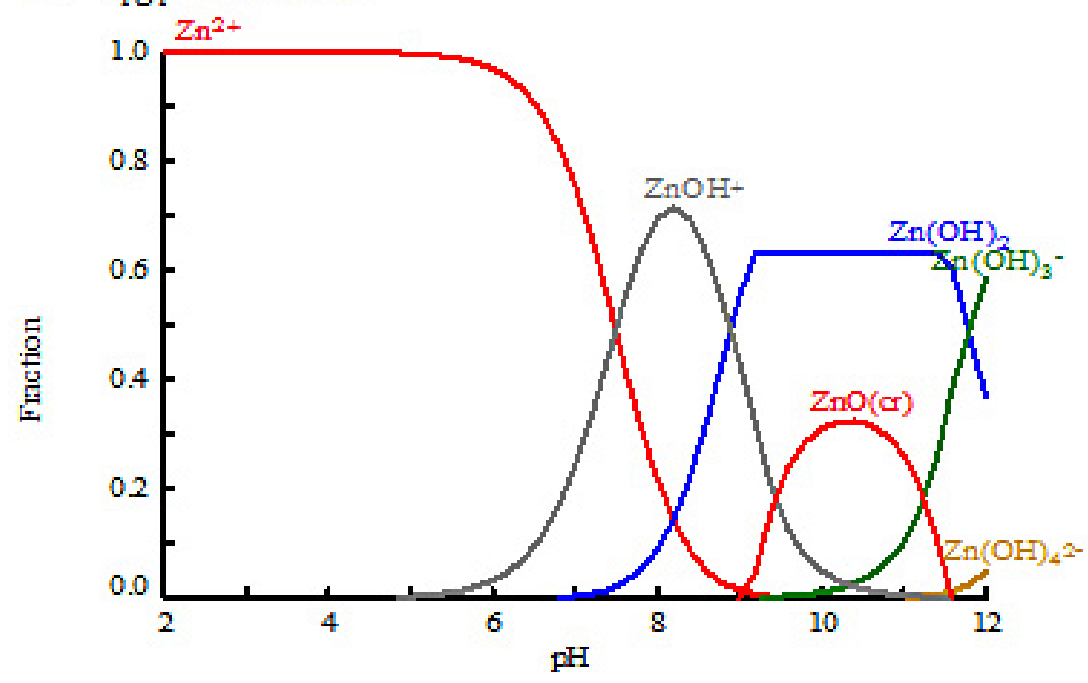

c) $\left[\mathrm{Pb}^{2+}\right]_{\mathrm{TOT}}=10.00 \mu \mathrm{M}$

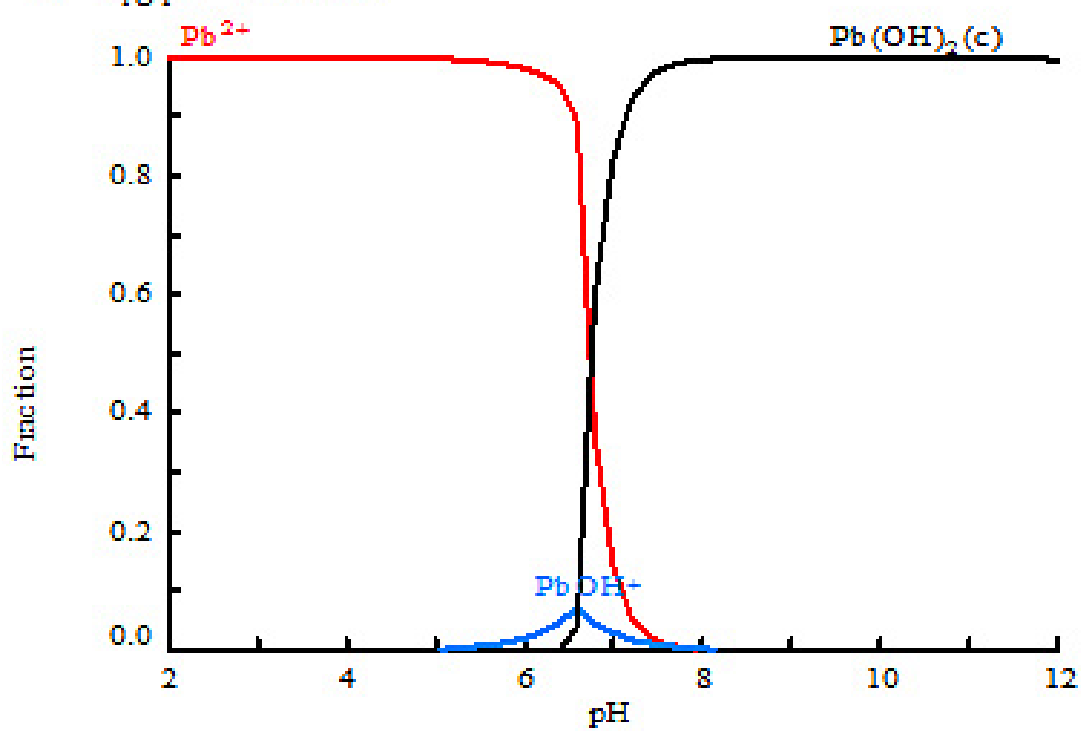

Figure 6. Speciation curves of a) $\mathrm{Cu}$, b) $\mathrm{Zn}$, c) $\mathrm{Pb}$ Comments: (c) - solid substance, (cr) - crystalline form 
Table 5. The content of $\mathrm{Cu}, \mathrm{Pb}$ and $\mathrm{Zn}$ in the soluble forms in fly ash $(\varphi=1,5 \mathrm{~mm})$ obtained by a variety relations of volume of $2.5 \%$ acetic acid $(\mathrm{pH}=2.5)$ to the mass of the sample - L:S (concentration of metal in the fly ash and the confidence interval were given for $\mathrm{n}=6$ at $\mathrm{p}=95 \%$ )

\begin{tabular}{|c|c|c|c|}
\hline \multirow{2}{*}{$\begin{array}{c}\text { Ratio } \\
\mathrm{L}: S \\
{\left[\mathrm{~cm}^{3}: \mathrm{g}\right]}\end{array}$} & \multicolumn{3}{|c|}{ Concentration of soluble forms of metal $\left[\mathrm{mg}^{\mathrm{k}} \mathrm{kg}^{-1}\right]$} \\
\cline { 2 - 4 } & $\mathrm{Zn}$ & $\mathrm{Cu}$ & $\mathrm{Pb}$ \\
\hline $2: 1$ & $2.5( \pm 0.2)$ & $2.5( \pm 0.2)$ & $<$ I.d. \\
\hline $5: 1$ & $2.5( \pm 0.1)$ & $2.4( \pm 0.1)$ & $<$ I.d. \\
\hline $10: 1$ & $14.9( \pm 0.7)$ & $2.4( \pm 0.5)$ & $12.4( \pm 0.9)$ \\
\hline $20: 1$ & $30.0( \pm 1.6)$ & $8.9( \pm 0.6)$ & $24.9( \pm 1.3)$ \\
\hline $50: 1$ & $29.4( \pm 1.6)$ & $8.7( \pm 0.7)$ & $24.0( \pm 1.6)$ \\
\hline
\end{tabular}

1. d. - limit of detection by FAAS method.

\section{Leachability as a function of time}

The execution time of the leaching test is an important parameter affecting the mobility and speciation of trace elements in fly ashes. The study of the effect of execution time of leaching of trace metals $(\mathrm{Cu}, \mathrm{Pb}$ and $\mathrm{Zn})$ from ash are essential from the perspective of the protection of the environment. The main objective of the research is to estimate the leaching time quantity of heavy metals in the soluble forms that are subject to migration, with the ash landfills in the wild in real life conditions. The results of these studies are necessary to assess the potential of the possible time of the release of the components of fly ash in the context of its liquidation in rendering specific conditions [Zandi et al., 2007]. The results obtained for this aspect of the study are shown in Figure 7. Time of leaching showed a significant impact on the concentration of $\mathrm{Cu}, \mathrm{Pb}$ and $\mathrm{Zn}$ in soluble forms. Copper concentrations were relatively constant for the execution time of the leaching test from 0.5 to $12 \mathrm{~h}$. For the leaching time equal to $24 \mathrm{~h}$, the contents of this metal increases. Lead showed a tendency to increase the concentration over the execution time of leaching test from 15 to $25 \mathrm{mg} \cdot \mathrm{kg}^{-1}$. Zinc, like lead, showed an increase to the highest concentration with increasing execution time of the leaching test. It achieved the highest concentration after 24 hours of leaching test duration.

Effects of selected organic compounds with a potential capacity of complexion the metals on the solubility of $\mathrm{Cu}, \mathrm{Pb}$ and $\mathrm{Zn}$ in anaerobic conditions

One of the effective ways of reducing the solubility of heavy metals is the use of probing by using specific groups of organic compounds, obtained by chemical synthesis or isolated from natural substances. For complexion compounds tartaric acid, citric acid, glucose were used. For complexion compounds of natural origin may be classified as humic substances. In order to determine the effect of selected organic compounds with a potential capacity of complexion of metals on the solubility of $\mathrm{Cu}, \mathrm{Pb}$ and $\mathrm{Zn}$ in anaerobic conditions, the fly ash made with the addition of complexion reagents i.e. tartaric acid, citric acid and glucose. The results of the concentrations of studied metals in the soluble forms in fly ash containing tartaric acid in the concentration range 10-200 $\mathrm{mg} \mathrm{dm}^{-3}$, the obtained after applying the TCLP test are shown in Figure 8. The presence of tartaric acid affects the concentration of the form soluble forms of $\mathrm{Pb}$. Namely, for $\mathrm{Zn}$ there was an increase in the concentration of metal in relation to the concentration of the metal in the soluble forms in the ash without tartaric acid, whereas for $\mathrm{Pb}$ it was reduced. The concentration of the soluble forms of $\mathrm{Cu}$ in the fly ash throughout the range of concentrations $\mathrm{C}_{4} \mathrm{H}_{6} \mathrm{O}_{6}$ is the same.

Figure 9 illustrates the changes in concentrations of metals in the soluble forms contained in the ashes under the influence of different concentrations of citric acid in the range of 10-100 $\mathrm{mg} \cdot \mathrm{dm}^{-3}$ introduced into the fly ash. The addition of citric acid to the fly ash caused an increase in the concentration of soluble forms of $\mathrm{Zn}$ in the ash as compared with to the fly ash no the complexion substances addition. This is different in the case of the other elements; for $\mathrm{Cu}$ concentration in the soluble forms decreased by half the value of the concentration of copper in the soluble forms in the fly ash with no citric acid addition, whereas for $\mathrm{Pb}$ it was equal to zero. Regardless of the value of the concentrations $\mathrm{C}_{6} \mathrm{H}_{8} \mathrm{O}_{7}$, the quantity of soluble forms of metal in the ash remains the same. Generally, the presence of citric acid is beneficial for leaching of $\mathrm{Zn}$, as compared to other elements.

The concentrations of the investigated metals in solutions obtained after leaching containing fly ash with addition of $200 \mathrm{mg} \cdot \mathrm{dm}^{-3}$ of glucose by TCLP procedure revealed no significant results. Comparing the results obtained with the concentrations of metals in the soluble form of fly ash with no glucose addition, an increased concentration of $\mathrm{Zn}$ can be seen. The contents of $\mathrm{Cu}$ and $\mathrm{Pb}$ in soluble forms has not changed significantly. 


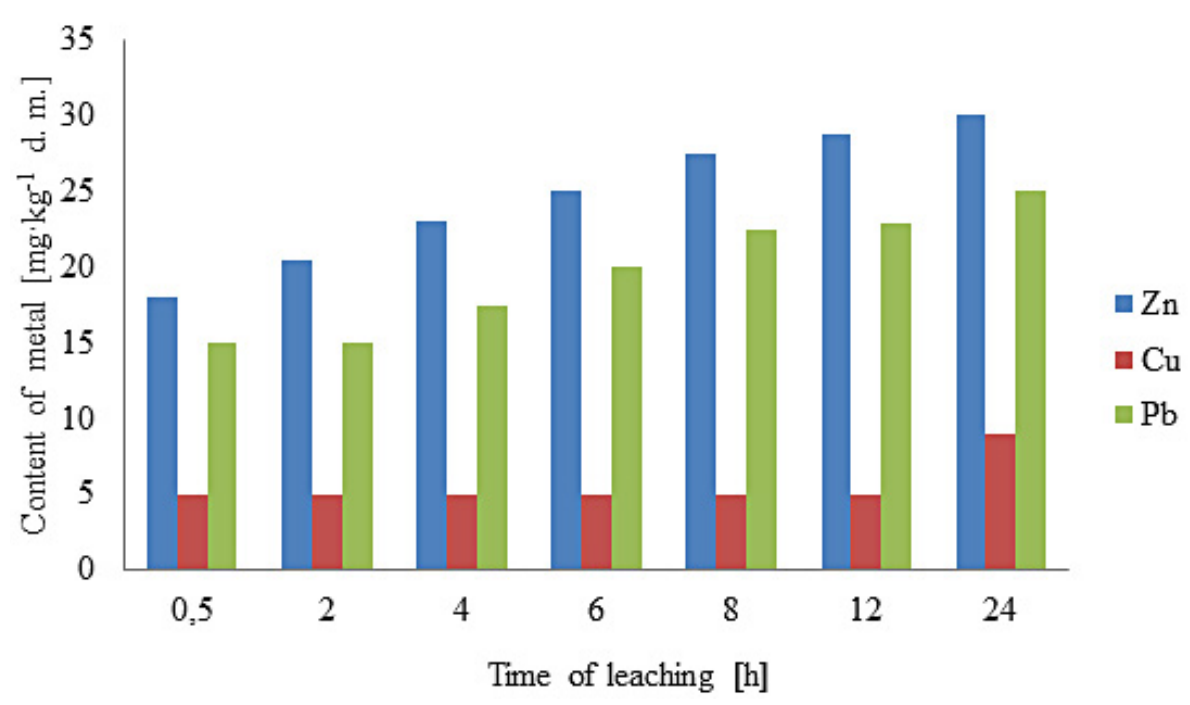

Figure 7. Relation between a time of leaching and the concentration of $\mathrm{Zn}, \mathrm{Cu}$ and $\mathrm{Pb}$ in the soluble forms in the fly ash having a grain diameter $\varphi=1.5 \mathrm{~mm}$, obtained by leaching with $2.5 \% \mathrm{CH}_{3} \mathrm{COOH}, \mathrm{pH} 2.5$

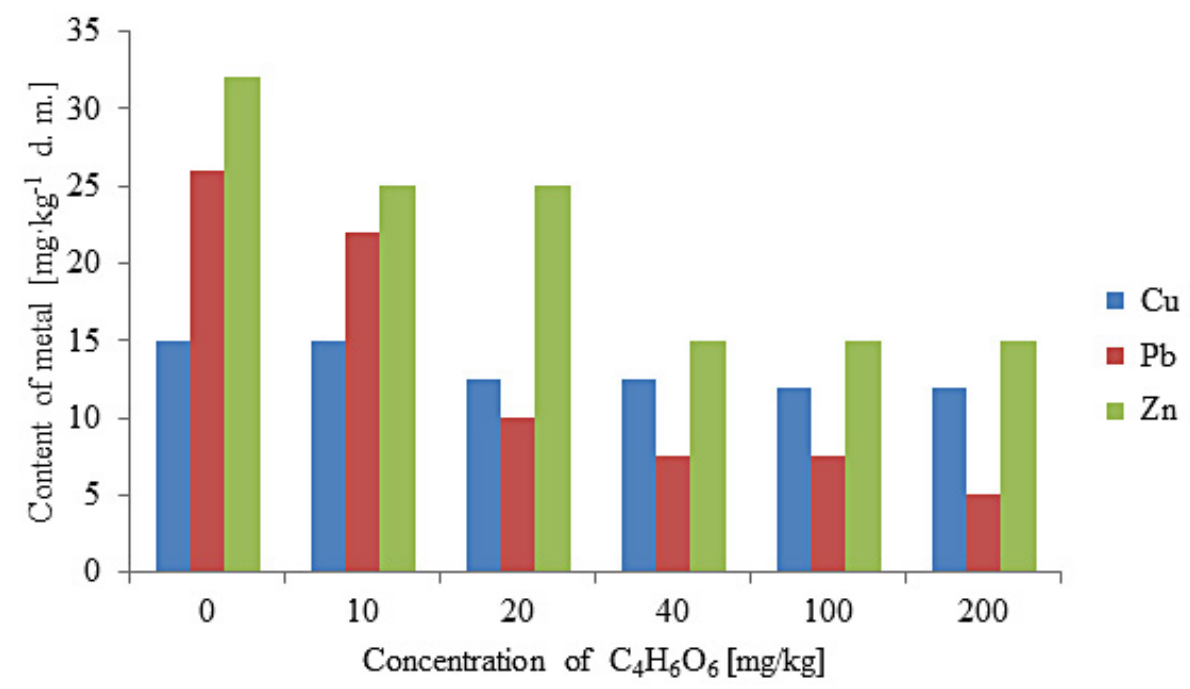

Figure 8. Changes of concentrations of soluble forms of $\mathrm{Zn}, \mathrm{Cu}$ and $\mathrm{Pb}$ in the fly ash with the addition of tartaric acid, obtained by the use the TCLP test

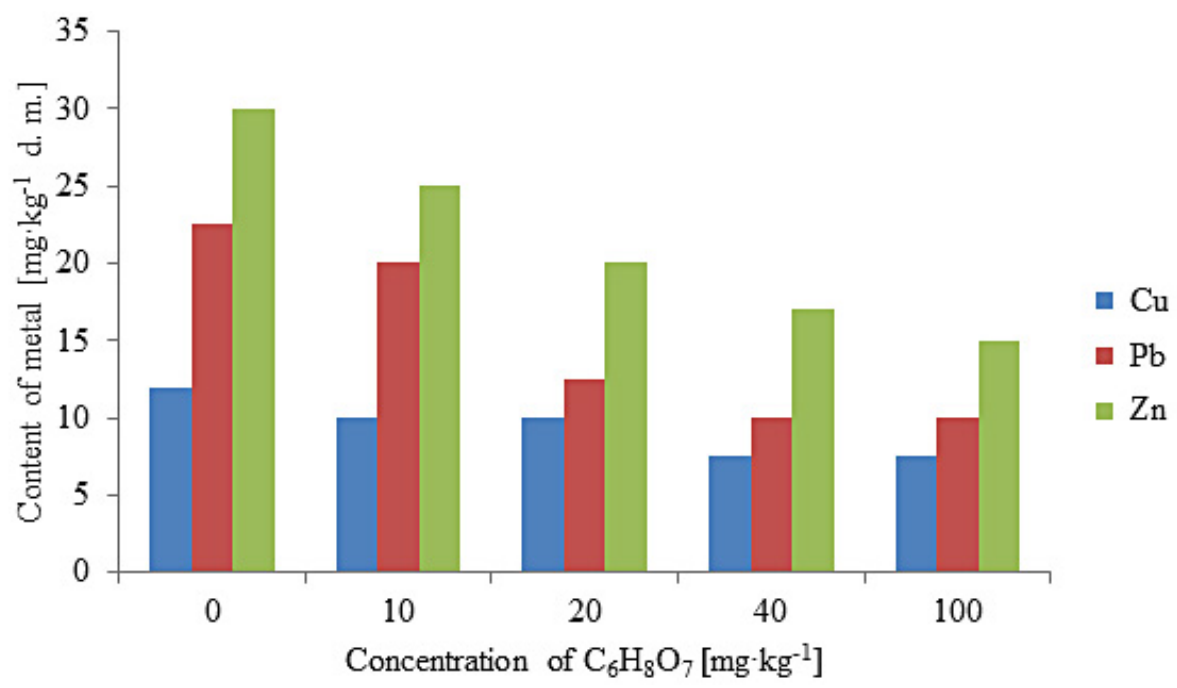

Figure 9. Changes of concentrations of soluble forms of $\mathrm{Zn}, \mathrm{Cu}$ and $\mathrm{Pb}$ in the fly ash with the addition of citric acid, obtained by the use the TCLP test 


\section{CONCLUSIONS}

1. The contents of metals in the soluble forms received after leaching the fly ash using the standard leaching testing exceeds the permissible concentrations of $\mathrm{Cu}, \mathrm{Pb}$ and $\mathrm{Zn}$ in relation to the standards for waste entering into waters or into the ground.

2. Considering, the solubility and mobility of heavy metals the fly ash can pose a threat to water and soils in the area of storage and storage creates the risk of inorganic contamination of the environment.

3. With regard to the ageing of inorganic waste, such as fly ash, it should be pointed out that monitoring both the composition and mobility of heavy metals present in the fly ashes is important.

4. Depending on the chemical composition of the leaching solutions and the diameter of the grains examined fly ash, exhibits a different level of mobility of $\mathrm{Cu}, \mathrm{Pb}$ and $\mathrm{Zn}$ in the soluble forms depending on the conditions of the leaching process.

5. On the basis of the conducted research it can be concluded that the optimal method for assessment of the impact of surface ash storage on the environment is the TCLP test made under the following conditions: particle diameter ash $\varphi=1.5 \mathrm{~mm} ; \mathrm{pH} 2.5 \% \mathrm{CH} 3 \mathrm{COOH}=2.5$; $\mathrm{L}: \mathrm{S}$ ratio $=(20) 50: 1$; leaching time $=24 \mathrm{~h}$.

6. In addition, it was found that the presence of organic compounds with a potential complexion of metals has a significant impact on the concentration of $\mathrm{Cu}, \mathrm{Pb}$ and $\mathrm{Zn}$ in soluble forms. Generally, the addition of tartaric or citric acid in the fly ash causes a decrease in the concentrations of metals in the soluble forms, with regard to ash without the above mentioned acids added after being applied of the TCLP test in optimal conditions.

7. Presence of glucose in fly ash caused an increase in the concentration of the soluble forms of $\mathrm{Zn}$ received by TCLP procedure compared to the concentrations of the metal in the soluble forms in fly ash with no glucose addition. The contents of $\mathrm{Cu}$ and $\mathrm{Pb}$ in the soluble forms has not been a significant change.

\section{REFERENCES}

1. Witkowska-Kit B., Zasucha J. 2000. Metody badań szkodliwego oddziaływania odpadów na środowisko, Utylizacja Odpadów Przemysłowych i Komunalnych, 2, 5-7 [In Polish].
2. Rozporządzenie Rady Ministrów z dnia 30.12.1997 r. w sprawie opłat za składowanie odpadów. Dz. U. RP, Nr162, poz. 1135 [In Polish].

3. Polska Norma PN-Z-15009/1997. Odpady stałe Przygotowanie wyciągu wodnego [In Polish].

4. Zandi M., Russel N.V. 2007. Design of a leaching test framework for coal fly ash accounting for environmental conditions. Environ. Monit. Assess., 131, 509-526.

5. Fällman A.M. Aurell B. 1996. Leaching tests for environmental assessment of inorganic substances in wastes, Sweden. Sc. Total Environ., 178, 71-84.

6. Fällman A.M. 1997. Performance and design of the availability test for measurement of potentially leachable amounts from waste materials. Environ. Sc. Tech., 31, 735-744.

7. Egemen E., Yurteri C. 1996. Regulatory leaching tests for fly ash: a case study. Waste Management \& Research, 14, 43-50.

8. Wahlström M. 1996. Nordic recommendation for leaching tests for granular waste materials. Sc. Total Environ., 178, 95-102

9. Lewin K. 1996. Leaching tests for waste compliance and characterisation: recent practical experiences. Sc. Total Environ., 178, 85-94

10. Quevauviller Ph., van der Sloot H.A., Ure A., Muntau H., Gomez A., Rauret G. 1996. Conclusions of the workshop: harmonization of leaching/ extraction tests for environmental risk assessment. Sc. Total Environ., 178, 133-139.

11. Galas K., Uliasz - Bocheńczyk A. 2005. Źródła i użytkowania popiołów lotnych ze spalania węgla w Polsce. Gospodarka Surowcami Mineralnymi, 21(1), 23-40 [In Polish].

12. Bilitewski B., Hardtle G., Merk K. 2003. Podręcznik gospodarki odpadami, Teoria i praktyka. Wydawnictwo Seidel-Przywecki Sp. z o.o, Warszawa, p. 45 [In Polish].

13. Pachowski J.2002 Rozwój technologii powstawania ubocznych produktów elektrownianych oraz ich charakterystyka i możliwości zastosowań w technologiach budownictwa drogowego. Drogi i Mosty, 1, 59-99 [In Polish].

14. Esakku S., Karthikeyan O.P., Nagendran R. 2008. Heavy metal fractionation and leachability studies on fresh and partially decomposed municipal solid waste. Practice Periodical of Hazardous, Toxic, and Radioactive Waste Management, 12, 127-132.

15. Sophia A.C., Swaminathan, K. 2005. Assessment of the mechanical stability and chemical leachability of immobilized electroplating waste. Chemosphere, 58, 75-82.

16. Janusa M.A., Bourgeois J.C., Heard G.E., Kliebert N.M., Landry A.A. 1998.Effectts of Particle and Contact Time one the Reliability of Toxicity Characteristic Leaching Procedure for Solidified/Stabilized Waste, Microchem. J., 59, 326-332. 
17. Gitari W.M., Fatoba O.O., Petrik L.F., Vadapalli V.R.K. 2009. Leaching characteristics of selected South African fly ashes: Effect of $\mathrm{pH}$ on the release of major and trace species. J. Environ. Sc. and Health Part A, 44, 206-220.

18. Lu S.G., Chen Y.Y., Shan H.D., Bai S.Q. 2009. Mineralogy and heavy metal leachability of magnetic fractions separated from some Chinese coal fly ashes. J. Hazardous Materials, 169, 246-255.

19. Jing C., Liu S., Korfiatis G.P., Meng X. 2006. Leaching behavior of $\mathrm{Cr}(\mathrm{III})$ in stabilized/solidified soil. Chemosphere, 64, 379-385.

20. Dermata S.D., Moon D.H., Menounov N., Meng X., Hires R. 2004. An evaluation of arsenic release from monolithic solids using a modified semi-dynamic leaching test. J. Hazardous Materials, 116, 25-38.

21. Mangialardi T. 2003. Disposal of MSWI fly ash through a combined washing-immobilization process. J. Hazardous Materials, 98, 225-240.

22. Sarode D.B., Jadhaw R.N., Khatik V.A., Ingle S.T., Attarde S.B. 2010. Extraction and leaching of heavy metals from thermal power plant fly ash and its admixtures. Polish J. Environ. Stud., 6, 1325-1330.

23. Fytianos K., Tsaniklidi B. 1998. Leachability of heavy metals in greek fly ash from coal combustion. Environ. Int., 4, 477-486.

24. Hardaway C., Gauthreaux K., Sneddon J., Beck J. 1999. Evaluation of contaminated sed-iments by toxicity characteristic leaching procedure extraction techniques. Microchem. J., 63, 398-404.

25. Praharaj T., Powell M.A., Hart, B.R., Tripathy S. 2002. Leachability of elements from sub-bituminous coal fly ash from India. Environ. Int., 27, 609-615.

26. Sitarz-Palczak E., Kalembkiewicz J., 2012. Study of remediation of soil contamined with heavy metals by coal fly ash, J. Environ.Prot., 3, 1373-1383.

27. Sitarz-Palczak E., Kalembkiewicz J., Zapała 1., 2008. A study of the chemical forms or species of manganese found in coal fly ash and soil, Microchem. J., 90, 37-43.

28. The Perkin - Elmer Corporation, Analytical Methods For Atomic Absorption Spectrophotometry, Norwalk Connecticut, USA, 1982.

29. Polska Norma Branżowa BN-81/0623-01. Popioły lotne i żużle z kotłów opalanych węglem kamiennym i brunatnym. Pobieranie i przygotowanie próbek [In Polish].

30. Polska Norma PN-77/G-04528-00.Paliwa stałe. Oznaczanie składu chemicznego popiołu. Przygotowanie próbki popiołu i roztworów do badań [In Polish].

31. Polska Norma PN-ISO-10390. Jakość gleby. Oznaczanie $\mathrm{pH}$ [In Polish].

32. Polska Norma PN-95/Z-15005. Oznaczanie zawartości węgla organicznego w kompoście z odpadów miejskich [In Polish].
33. Polska Norma PN-R-04032. Gleba i utwory mineralne - Pobieranie próbek i oznaczanie składu granulometrycznego [In Polish].

34. Łączny J.M. 2002. Model matematyczny oddziaływania składowisk odpadów energetycznych na środowisko. Zakład Narodowy im. Ossolińskich, Wrocław, p. 16 [In Polish].

35. Su D.C., Wong J.W.C. 2003. Chemical speciation and phytoavailability of $\mathrm{Zn}, \mathrm{Cu}, \mathrm{Ni}$ and $\mathrm{Cd}$ in soil amended with fly ash-stabilized sewage sludge. Environ. Int., 29, 895-900.

36. Antonkiewicz J. 2014. Effect of fly ashes and sewage sludge on $\mathrm{Fe}, \mathrm{Mn}, \mathrm{Al}, \mathrm{Si}$ and Co uptake by grass mixture. J. Ecol. Eng., 3, 6-13.

37. Izquierdo M., Quero X. 2012. Leaching behavior of elements from coal combustion ash; an overvirw. Int. J. Coal Geology, 94, 54-66.

38. Choi S.K., Lee S., Song Y.K., Moon H.S. 2002. Leaching characteristics of selected Korean fly ashes and its implications for the groundwater composition near the ash disposal mound. Fuel, 81, 1083-1090.

39. Reardon E.J., Czank C.A., Warren C.J., Dayal R., Johnston H.M. 1995. Determining controls on element concentrations in fly ash leachate. Waste Manag. Res., 13, 435-450.

40. Steenari B.M., Schelauder S., Lindqvist O. 1999. Chemical and leaching characteristics of ash from combustion of coal, peat and woo in a $12 \mathrm{MW} \mathrm{CFB}$ - a comparative study. Fuel, 78, 249-258.

41. Cho H., Oh D., Kim K. 2005. A study on removal characteristics of heavy metals from aqueous solutions by fly ash. J Hazardous Materials, 127, 187-195.

42. Lee M.K., Saunders J.A. 2003. Effect of pH on metals precipitation and sorption: Field bioremediation and geochemical modeling approaches. Vadose Zone J., 2, 1770-185.

43. Ho Y.S., Huang C.T., Huang H.W. 2002. Equilibrium sorption isotherm for metal ions on tree fern. Process Biochemistry, 37, 1421-1430.

44. Cuppett J.D., Duncan S.E., Dietrich A.M. 2006. Evaluation of copper speciation and water quality factors that affect aqueous copper tasting response. Chemical Senses, 31, 689-697.

45. Zirino A., Yamamoto S. 1972. A pH-dependent model for the chemical speciation of copper, zinc, cadmium and lead in seawater. Limnology and Oceanography, 17, 661-671.

46. Cárdenas-López C., Camargo G., Giraldo L., Moreno-Piraján J.C. 2007. Design of an adsorbent employing activated carbon fiber to remove lead. Ecletica Quimica, 32, 61-72.

47. Deliyanni E.A., Peleka E.N., Matis K.A., 2007. Removal of zinc ion from water by sorption onto iron-based nanoadsorbent. J. Hazardous Materials, 141, 176-184. 